THURSDAY, DECEMBER I2, I872

\section{SCIENTIFIC RESEARCH AND UNIVERSITY ENDOWMENTS}

NOTWITHSTANDING the great development of scientific education, and the firm and prominent position which Science holds in public estimation, it must be admitted that a profound dissatisfaction and anxiety are the prevailing feelings with which the conditions and prospects of English science are regarded by the cultivators of knowledge. To the outside observer these sentiments appear simply captious and unreasonable. When so much has been done, why on earth should we complain? The truth, however, unhappily is, that in the midst of our apparent abundance we have still a great deficiency; and those fruits and results of Science, in the way of scientific research and discovery, which afford the true measure of our scientific condition, have by no means proportionably increased. Indeed it may be doubted whether the annual harvest of scientific truth is even as abundant as twenty or thirty years since, when Science had hardly penetrated even the outer crust of English society. The character of our scientific periodicals is essentially altered. The Journal of the Chemical Society, for example, of which the original and proper function was to print the investigations of English chemists, now appears to exist simply to inform us of what is accomplished elsewhere. The volume for the year $187 \mathrm{r}$ is a stout octavo of $\mathbf{1 , 2 2 4}$ pages; of these, however, not more than 154 are occupied with original communications read before the Society, while the rest of the volume is filled with innumerable abstracts of the investigations of the chemists of Germany and France. Ten years ago the same journal contained. on the average at least 400 pages of original matter.

Now, the perfection of science, in all the various aspects in which it appears as an instrument of human progress, is manifested only in scientific inquiry; and to the scientific mind no technical skill, no abundance of information, can be a substitute for this, or compensate for its absence.

This view of the condition of Science is not invalidated by the circumstance that a certain number of distinguished Englishmen are to be found whose scientific work is of the highest order.

In this country there are now, as has been the case in each generation for the last two hundred years, a limited number of individuals of powerful intellect and elevated aspirations, who have made scientific research the main purpose and object of their lives. 'Of such we have happily sufficient living examples to preserve among us the true type of the scientific investigator, and to dispel the apprehension of intellectual degeneracy. The labours, however, of modern Science are on far too extensive a scale to be carried on simply by the efforts of eminent individuals. Science requires the services of a class devoted to the extension of knowledge, precisely as other classes of society are devoted to commerce, to politics, or to agriculture. Such a class does not exist among us, and its absence is the greatest defect in our social system.

Undoubtedly there are many causes which interfere with the growth of such a class. The unremuneraNo. 163-VoL. viI. tive character of scientific work, the want of intelligent appreciation on the part of the public, of even the value and importance of such work by which the student is deprived of that most powerful stimulus to exertion, the sympathy and support of others, deter many from the career of Science. Moreover, the very spread of scientific knowledge and education is, in its results, by no means in all respects favourable to the pursuit of pure Science. A demand is created for the services of scientific men in a technical direction which it is very difficult to meet, and which induces the student of Science to turn his attention to the practical and remunerative rather than to the theoretical aspect of his vocation. Many a man, too, of genius for research is compelled by the sad necessities of life to labour at the oar for the service of the community, is drafted into the ranks of popular lecturers to amuse the public with ready talk and brilliant experiments, or spends a life which he would willingly devote to scientific investigation as an officer of health, or an analytical and manufacturing chemist.

Such impediments, however, to the indulgence of men's higher tastes and desires, have their root in the very organisation and necessities of modern society, and are not peculiar to English life. But Science has in this country one special difficulty to contend with-the utter apathy in regard to the advancement of knowledge which has so lon g prevailed at the English Universities, which, without any doubt, is the main cause of our disasters. In Germany the universities are the very centres of intellectual progress; and we might reasonably have hoped that here also amid the distractions of modern life these great institutions would have afforded at least one refuge for science and learning, and have supplied the few who might possess any exceptional capacity for these pursuits with the means of existence and the means of work. Such, indeed, was undoubtedly the main object to which these noble institutions were destined by their founders, who equipped them with all the appliances necessary for the cultivation of the knowledge of their day. But, unfortunately, they fell into wrong hands, and the class to whose protection and care these great interests were confided betrayed in every way the trust committed to them; until at length abuses reached such a point that, after a prolonged agitation, university reformers succeeded in obtaining the interference of the Legislature in the form of the Executive Commission of 1854 . The unsatisfactory way in which this commission proceeded to remedy the evils complained of is even now not generally understood.

When we consider the profound importance of learning and scientific discovery, not alone to the material and physical, but also to the intellectual and moral progress of the nation, we might well have anticipated that in any reform of the universities the first object of our statesmen and legislators would have been to provide for these great interests, and to restore the endowments of the university in this respect to their ancient uses. But the commission did nothing of the kind ; its efforts were mainly directed to the suppression of pecuniary jobbery. But this having been effected, the further changes which they introduced proceeded upon the lowest possible estimate of the functions of an University, which they appear to have regarded not at all as a national instrument for the 
furtherance of knowledge, but simply as a superior kind of Grammar School. Of the University, as thus understood, pecuniary prizes were to be the motive power, and competitive examination the regulating principle. The resources of the colleges were dealt with from this point of view. Numerous scholarships were founded for the support of students, on a scale so extensive, that, as has been computed, one-third of the students of Oxford are thus subsidised during their University career. The remainder and greater part of the endowments was nearly all devoted to fellowships, varying in value from $200 l$. to $300 \%$. a year ; on these two objects it is estimated that at least $120,000 \%$. is anmually expended by the colleges of Oxford.

The fellowship which they thus created is indeed a unique and singular institution. It is a life-estate conferred by a corporate body, without exacting in return any services whatever from its possessor, either to the college or to the community at large; and the chief result of the labours of the Executive Commission, whose business it was to reform the University, was the establishment of this gigantic system of sinecure pensions, conferred upon young men in the prime and vigour of life, as the reward of having passed a successful examination. When the ordinances framed by the Commissioners come fully into operation, there will be, in Oxford alone, about 300 sinecure fellowships.

In the arrangements of the Commissioners the most contemptuous disregard was manifested for the interests of science and learning. A few professorships of ancient date founded by men of a very different stamp, which the colleges had suppressed, were revived, but no real or adequate provision was made even for the maintenance of lecturers and professors necessary to carry on the education of the place, and out of these vast funds, not a sixpence was devoted to the advancement of knowledge or the promotion of scientific or literary research, or to the support of museums and laboratories.

These arrangements were not based upon any very high estimate of human motives and desires, and it would have been surprising indeed if an ideal University, devoted to the interests of learning, knowledge, and truth, should have sprung from such ashes. As a matter of fact, complaints are heard on all sides of the futility of this system, and the necessity of a redistribution of the college endowments is widely felt. In this movement the Government have taken the initiative by the appointment of a Royal Commission to inquire into the revenues of the Universities and Colleges of Oxford and Cambridge. These revenues have never as yet been fully disclosed, but we may anticipate that a good deal of surprise and even indignation will be felt when the amplitude of these re. sources is contrasted with the inadequate results attained by them. Another contingency will then arise, to be deprecated by every lover of knowledge, the possible alienation and dissipation of the noble inheritance of science and learning which has been so inappropriately employed.

It was in connection with these questions and with the view of considering the best application, in the interests of mature study and scientific research, of the endowments of the Universities and Colleges of Oxford and Cambridge that the public meeting was held at the Freemasons' Tavern on November 16, of which the report appeared in this journal on November 28. The spirit and purpose of those present at this meeting will be best understood from the resolutions passed by it. These resolutions were :-

I. That to have a class of men whose lives are devoted to research is a national object.

2. That it is desirable, in the interest of national progress and education, that professorships and special institutions shall be founded in the Universities for the promotion of scientific research.

3. That the present mode of awarding fellowships as prizes has been found unsuccessful as a means of promoting mature study and original research, and that it is desirable that it should be discontinued.

4. That a sufficient and properly organised body of resident teachers of various grades should be provided from the Fellowship Fund.

The Society for the Organisation of Academical Study, founded at this meeting, is constituted by no meatis in the exclusive interests of the natural sciences, but for the sake of the totality of knowledge. The apprehensions which are felt in regard to the condition of research in the physical sciences, are similarly and equally felt in other departments of knowledge, and the objects of this Society are such as to secure the good-will and adhesion of every genuine student. Much cotisideration will be necessary to devise really practical arrangements, by which such ideas may be carried out. On this point the evidence of those distinguished persons who have been examined before the Science Commission will be of the greatest value; but it is to be hoped that all those who are familiar with the requirements of the several departments of Science will turn their serious attention to the subject, and give to the Society the benefit of their co-operation and advice, with the view of hereafter laying before the Government an adequate and practical scheme for the re-constitution of the Colleges and Universities, not simply as educational bodies; but as national foundations for the preservation and extension of knowledge.

B. C. BRODIE

\section{THE METEOROLOGY OF THE FUTURE}

$\mathrm{T}$ would be a curious inquiry which we commend to I those learned in statistics, to determine how many millions of observations have been made in the British Isles on dry and wet bulb thermometers, on barbinieters, and on other meteorological instruments. It would be a still more curious inquiry, seeing that the infinite industry displayed in these observations shows that the importarice of the study of Meteorology is universally conceded, to determine why it is that meteorologists, state-endowed and otherwise, have, as a rule, been content to grope their way in the dark, and not only not- seek to find, but persistently refuse the clue, which, if followed, would bring them into the light of day. When some one some centuries hence-thank heavens, we have always that to look to in all branches of research-comes to consider the work done by meteorologists during the present century, he will, unless he be some patient German Dryasdust determined to examine all minutes of Boards of Visitors, all Kew Committee Records, and the like, give up the task in the most utter despair, and on the whole pethaps this is the best thing that could happen. 